\title{
Do We Need a New Leadership Paradigm Due to Covid-19?
}

\author{
Lisbeth Claus \\ Professor of Management and Global HR, Willamette University MBA, Salem, Oregon, USA \\ *Correspondence: Lisbeth Claus, Email: 1claus@willamette.edu
}

\begin{abstract}
Explores whether the changing context of COVID-19 requires new leadership skills in organizations and, perhaps even, a new context-specific leadership theory. Fourteen professional blogs and reports related to leadership skills and practices in response to COVID-19, published in the professional online literature during the height of the pandemic (March 16 December 20,2020) were reviewed in terms of suggested new leadership style dimensions and contrasted with the tenets of existing academic leadership theories. The proponents of an emerging leadership style advocate that in dealing with the pandemic, leaders must be able to manage their organizations in turbulent times, lead a distributed workforce of individuals and teams, and become a resilient leader themselves.
\end{abstract}

Synthesis: The analysis suggests the leadership dimensions called for during the pandemic were already present in transformational leadership theories (e.g., authentic, shared feminine, servant and crisis leadership theories) but that the pandemic provided the structural break accelerating the existing transformational leadership paradigm. COVID-19 also confirmed leadership matters and the command-and-control leadership style — still prevalent in many of our top-down bureaucratic organizations-is outdated.

Keywords: Leadership, COVID-19

\section{ARTICLE INFORMATION}

Author(s): Lisbeth Claus

Received: 24 Feb, 2021; Accepted: 17 Apr, 2021; Published: 22 May, 2021; e-ISSN: 2347-4696;

Paper Id: BMN-IJBMR-2021-27;

Citation: doi.org/10.37391/IJBMR.090206

Webpage-link:

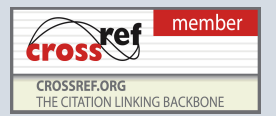

https://ijbmr.forexjournal.co.in/archive/volume-9/ijbmr-090206.html

\section{INTRODUCTION}

COVID-19 is the impetus for people to argue that a new leadership paradigm is needed. How do we redefine leadership practice in the changing context of COVID-19? Since the spread of the pandemic, a number of professionally circulating editorials, opinion blogs, articles, and reports have been arguing that the disruption in the workplace requires a new set of leadership skills due to the 'Covid effect'. Crucible events like a global pandemic are often responsible for creating disruption [1]. Without doubt, the changing context due to COVID-19 provided the structural break that was the impetus for a significant management paradigm shift needed for the $4^{\text {th }}$ industrial revolution. The coronavirus not only accelerated managing in a new world of work but made disruption a mainstream reality for all companies. Within a matter of weeks, companies around the world and their employees made a successful shift to the 'dynamic open talent' paradigm [2] including work from home that could have taken decades without the unpredicted precedent of a global pandemic.

\section{LITERATURE REVIEW}

Leadership is both a science (based on theories and empirical evidence) and an art (based on daily practice). There is a vast body of literature on leadership and more business books on leadership than on any other management topic. Leadership is context-specific in terms of time and place. Classic leadership theories have evolved as a result of the changing worldviews and empirical examination of the basic premises of each theory. Over time, all subsequent (leadership) theories refute, confirm, or refine the 'originals.' The extant leadership theories can be classified in various ways. This review of leadership theories uses a chronological timeline and common headings to organize the theories in groups with similar reference frames and tenets.

The Great man theory is one of the earliest leadership theories based on historical studies of great men. Leadership was attributed to individuals who have inborn characteristics. According to this theory, a person capable of leading has the personality traits (e.g., charm, confidence, intellect, communication skills, and social aptitude) of a leader from birth, which set them apart from others (i.e., the masses). Example of the hereditary trait leadership theory is Thomas Carlyle's Great Man Leadership [3]. Trait theories also view leadership ability as innate ('born') and based on distinctive physical and mental traits. Example of the trait leadership theory is Francis Galton's hereditary leadership [4]. Leadership traits mentioned are intelligence, clear and strong values, and a high level of personal energy [5]. It should be noted that the great man and trait leadership theories are denounced as pro-eugenics (i.e., people are born better). In behavioral theories, the focus is on leadership behaviors rather than traits. Leadership effectiveness relates to how people behave and act. Effective leadership is the result of many learned or acquired skills (i.e., an individual can learn to become a good leader by taking specific actions). The goal is to identify dimensions of leadership behavior associated with performance effectiveness. In the Ohio State University studies, initiating structure and showing consideration are two dimensions of leadership behavior [6]. The University of 
Michigan research focuses on employee-centered and production-centered behaviors [7]. Contingency theories propose that no one way or style of leadership may be applicable to all internal and external dimensions of an environment. In other words, there are variables influencing any particular situation, and a leader must choose the right course of action while taking into account those variables. Situational leadership - the most developed contingencies theory-stresses the importance of situational variables, and doesn't consider any one leadership style to be better than the others. Situations differ, and the most appropriate leadership qualities and actions vary from situation to situation. The best styles of leadership depend on the qualities of the leader, the characteristics of the follower, and the nature of the situation. In contingency leadership theories, the leader is the focus in the leader-subordinate relationship. In situational leadership theories, subordinates play a pivotal role in the leader-follower dyad. Examples of contingency/situational leadership theories are Martin Evans and Robert House's path-goal theory of leadership [8, 9] Fred Fiedler's contingency model and least preferred co-worker theory [10], Fred Fiedler and Joe Garcia's cognitive resource leadership theory [11], Paul Hersey and Ken Blanchard's situational leadership model [12, 13], and Robert Blake and Jane Mouton's managerial grid [14]. Style leadership theories search for attributes and competencies that exemplify the leaders rather than their traits. Leadership requires vision and is a matter of style as well as substance. Examples of style leadership theories are Kurt Lewin's leadership styles [15], Warren Bennis' leadership theory [16, 17], Jim Collins' 5-level leadership [18] and John C. Maxwell's 5 levels of leadership [19]. Transactional theories of leadership revolve around the role of supervision, organization, and teamwork. Transactional leaders guide or motivate their followers in the direction of established goals by clarifying role and task requirements and consider rewards and punishments as the basis for leadership actions and employee motivation. Examples of transactional leadership theories are: Fred Dansereau, George Graen, and William Haga's Leader-Membership Exchange [20, 21] and John Adair's Action-Centered Theory [22]. In transformational theories of leadership, leaders use personal qualities to transform individuals (e.g., charisma, inspiration, stimulation, individualism). Leaders have a profound and extraordinary effect on their followers and inspiring the latter to transcend their own self-interest for the greater good of the organization. Examples of transformational leadership theories are James MacGregor Burns' transformational leadership theory [23], Bernard Bass' transformational leadership model [24, 25], Bruce Avolio and Fred Luthans' authentic [26-29], Stephen Covey's principled leadership [30, 31], Deepak Chopra's soul leadership [32], Daniel Goleman, Richard Boyatzis, and Annie McKee's primal leadership [33], Richard Boyatzis and Annie McKee's resonant leadership [34], James Kouzes and Barry Posner's leadership participation inventory [35] Manfred Kets de Vries' mystique leadership [36]. Around the year 2000, global leadership theorists searched for a global model of leadership effective in multi-cultural and international environments, implying that existing leadership theories may not be applicable or reliable in other countries and international environments. Examples of global leadership theories are Jean Lipman-Blumen's connective leadership [37], Stewart Black, Allen Morrison, and Hal Gregersen's global explorers [38], Fons Trompenaars and Charles Hampden-Turner's dilemma reconciliation [39], Robert House et al.'s G.L.O.B.E. research program [40] and Mark Mendenhall and Joyce Osland's global leadership competencies [41]. In servant leadership, the leader is a servant-first rather than a leader-first. The leader ensures other people's highest priority needs are being served by enriching the lives of individuals and building better organizations, creating hereby a more just and caring world. Many of the transformational leadership theories have a servant leadership component. Examples of servant leadership are Robert K. Greenleaf's servant leadership [42] and Agile leadership [43]. Feminine leadership acknowledges the feminine dimension in the leadership of men and women by focusing on feminine attributes rather than a predominantly masculine style of leadership exhibited in male and female leaders highlighting an inclusive leadership style - a women's way of leading. Examples of feminine leadership are Sally Helgesen's feminine leadership [44] and Tomas Chamorro-Premuzik's women's leadership competency gap [45]. As teamwork becomes more prevalent, appointing someone as a leader is substituted by shared leadership (aka distributed, collective, and horizontal leadership) distributes leadership in organizations to the members of a team, whereby people lead and influence each other through collaborative decisionmaking and shared responsibility for outcomes and leaders emerge. Examples of shared leadership are Craig L. Pearce and Jay A. Conger's shared leadership [46] and James Kouzes and Barry Posner's participation leadership (X). Crisis leadership theories focus on leading in 'extremis' (crisis) situations such as downturns in business, national disasters, massive product recall, workplace violence, and sexual harassment and ethical scandals. Example is André J. DuBrin's crisis leadership [47].

\section{MATERIALS AND METHODS}

This article explores whether the changing context as a result of the 'COVID effect' requires also new leadership skills and perhaps even a new context-specific leadership theory. Using multiple sources, we reviewed 14 professional blogs and reports published online during the height of the pandemic (from March 16 to December 20, 2020) related to leadership skills and practices discussed in response to COVID-19 (Table 1). These professional publications had a common theme namely new leadership skills are required because of COVID19. Using content analysis [48], the suggested dimensions of the proposed new leadership style found in the recent professional literature is compared the tenets of traditional academic leadership theories. Leadership theories as commonly taught in management schools have evolved over the past 70 years (ca 1950-2020), and traditionally been categorized under different headings including behavioral, contingency, situational, style, transactional, transformational, global, servant, feminine, shared, and crisis leadership theories [49]. 


\section{RESULTS}

The proponents of an emerging leadership theory due to COVID-19 advocate that to deal with the pandemic, leaders must be able to manage their organizations in turbulent times, lead a distributed workforce of individuals and teams, and become a resilient leader themselves (Table 1).

\begin{tabular}{|c|c|}
\hline \multicolumn{2}{|r|}{ Leading Organizations in Turbulent Times } \\
\hline Strategic thinking & $\begin{array}{l}\text { - Put the mission first [50]. } \\
\text { - Take holistic views of specific outcomes [51,52]. } \\
\text { - Have the ability to look at things systemically [53] } \\
\text { - Reorient your road map with sense making [54]. } \\
\text { - Have some understanding of interrelationships to understand long-term developments [53]. } \\
\text { - Embrace the long-term view [50]. } \\
\text { - Focus on the likely outcomes [55]. }\end{array}$ \\
\hline $\begin{array}{l}\text { Uncertainty } \\
\text { management }\end{array}$ & $\begin{array}{l}\text { - Prepare for and adapt to increased turbulence [54] } \\
\text { - Be comfortable with ambiguity [51,52]. } \\
\text { - Get comfortable with widespread ambiguity and chaos quickly [55]. }\end{array}$ \\
\hline Decision- making & $\begin{array}{l}\text { - Make decisions amid uncertainty [56] } \\
\text { - Embrace rapid decision-making [51, 52]. } \\
\text { - Aim for speed over elegance [50]. }\end{array}$ \\
\hline Change management & - Navigate and manage change quickly and appropriately [57]. \\
\hline Reinvention & $\begin{array}{l}\text { - Create new rules of the road with your team [58]. } \\
\text { - Be creative and entrepreneurial }[51,52] \text {. } \\
\text { - Increase resilience through reinvention [58]. }\end{array}$ \\
\hline \multicolumn{2}{|r|}{ Leading a Distributed Workforce (Individuals and Teams) } \\
\hline $\begin{array}{l}\text { Employee experience } \\
\text { and support }\end{array}$ & $\begin{array}{l}\text { - Design from the heart } \ldots \text { and the head [50]. } \\
\text { - Make wellbeing a priority [58]. } \\
\text { - Put care at the center of leadership [54]. } \\
\text { - Be supportive and caring [51,52]. } \\
\text { - Give special attention and care to work [54]. } \\
\text { - } \text { Bester a culture that enables employees [54]. } \\
\text { - Cultivate strong morale among their followers [55]. }\end{array}$ \\
\hline $\begin{array}{l}\text { Emotional intelligence } \\
\text { and empathy }\end{array}$ & $\begin{array}{l}\text { - Possess a solid dose of emotional intelligence and a solid sense of self-worth to be able to withstand } \\
\text { the pressures that come with the job [53]. } \\
\text { - Foster a sense of belonging to combat isolation and loneliness [58]. } \\
\text { - Have emotional agility [59]. } \\
\text { - Remain culturally sensitive and emotionally aware [57]. } \\
\text { - Demonstrate empathy [56,59,60]. } \\
\text { - Address the fear of their followers without feeding it [55]. }\end{array}$ \\
\hline Trust & $\begin{array}{l}\text { - Connect with people as individuals and establish mutual trust [61]. } \\
\text { - Promote an open and trusting environment }[51,52] \text {. } \\
\text { - Build social capital [62]. }\end{array}$ \\
\hline Flexibility & - Be flexible and adaptable [60]. \\
\hline Communication & $\begin{array}{l}\text { - Communicate effectively [56]. } \\
\text { - Communicate frequently in a consistent format or medium [55]. } \\
\text { - Communicate clearly and often with all stakeholders [61]. } \\
\text { - Use consistent reliable fact-based communications [60]. } \\
\text { - Engage in active listening [60]. } \\
\text { - Have candor [60]. } \\
\text { - Move deftly between presenting brutal honesty and credible hope [55]. } \\
\text { - Own the narrative [50]. }\end{array}$ \\
\hline Team skills & $\begin{array}{l}\text { - Manage the context and be more intentional about how we come together [59]. } \\
\text { - Organize via a network of teams [56]. } \\
\text { - Emphasize the power of community [55]. } \\
\text { - Build strong and cohesive teams with employees working remotely [57]. } \\
\text { - Manage hybrid teams [60]. } \\
\text { - Unleash the collective genius of your team [54]. }\end{array}$ \\
\hline
\end{tabular}




\begin{tabular}{|l|l|}
\hline & $\begin{array}{l}\text { - Emphasize work-life balance for your teams [54]. } \\
\text { - } \text { Be able to lead teams virtually without face-to-face interaction [62]. }\end{array}$ \\
\hline Empowerment/ & $\begin{array}{l}\text { - Empower and delegate to others [54]. } \\
\text { - Build shared understanding through dialogue [54]. } \\
\text { Delegation }\end{array}$ \\
\hline \multicolumn{2}{|c|}{ Distribute leadership throughout the organization [61]. } \\
\hline $\begin{array}{l}\text { Resilience and self- } \\
\text { care }\end{array}$ & $\begin{array}{l}\text { Being a Resilient Leader } \\
\text { - Display deliberate calm and bounded optimism [56]. } \\
\text { - Have a reflective capability [53]. } \\
\text { - Show humility [60]. } \\
\text { - Have a strong ethical compass to avoid the corruptive influences that may come with the job [53]. }\end{array}$ \\
\hline
\end{tabular}

Table 1: New Leadership Practices and Skills Due to COVID-19.

The analysis shows the 'COVID-effect' has definitely produced a shift in the importance of certain leadership behaviors to deal with the new ambiguity. The so-called new leadership skills focus on:

1. Leading organizations in turbulent times-during the pandemic, leaders must not only strategically lead their organizations during the current crisis and achieve the desired work outcomes requiring dealing with change by making rapid decisions, but also reposition the organization for the long-term future.

2. Leading, managing, and coaching a distributed (virtual) workforce of individuals and teams - the new leadership skills emphasize more caring and supporting behaviors toward employees, showing emotional intelligence, having empathy, being flexible, and building trust in order to enhance the experience of employees doing their job mostly from home under the new and more stressful circumstances.

3. Building resilience-leaders must practice self-care, put their oxygen mask on first, and build resilience in themselves, requiring a great deal of humility.

The results indicate that the so-called new demands on leaders due to the COVID-effect require leading under uncertainty, managing a distributed workforce, and building resilience.

\section{DISCUSSION}

Is the shift in the demand for leadership skills calling for a new theory? Are we really dealing with a new leadership paradigm or is the pandemic the structural break that accelerated the paradigms that were already in place but, perhaps, not fully accepted? The analysis suggests that many of the leadership dimensions called for during the pandemic were already present in the more recent leadership theories. Several of the well-established transformational rather than transactional leadership models of the past decades have called for these leadership styles prior to the pandemic. The new leadership skills to respond to COVID-19 proposed in the professional literature are already part of transformational, resonant, shared, feminine, servant and crisis leadership theories:
- Transformational leadership - based on the premise that cultural, social, emotional intelligence, and the authenticity of leaders matter, as well as their ability to change their followers [23].

- Resonant leadership - based on the concept of emotional intelligence and focused on the development of resilience [34].

- Shared leadership-leadership is distributed to the members of a team and people lead and influence each other through collaborative decision-making and shared responsibility for outcomes [63].

- Feminine leadership - emphasizes a dimension caring in leaders [44].

- Servant leadership_leaders ensure other people's highest priority needs are being served by enriching the lives of individuals, building better organizations, and creating a more just and caring world [42].

- Crisis leadership-leaders deal with requirements of internal and external stakeholders of the organizations during a crisis situation [47].

In their 2002 book entitled, The Leadership Challenge, Kouzes and Posner argue that the basic principles of leadership are the same and do not change, but the context is different. Hence, each generation has to redefine leadership in its own context [35]. While basic leadership principles have changed little over time, the context has changed dramatically. The results indicate that COVID-19 did not engender a new leadership theory, but is an amalgam of the already existing transactional and transformational leadership frameworks. COVID-19 is the structural change that confirmed that the command-andcontrol leadership style - still prevalent in many of our topdown bureaucratic organizations - is outdated and a new definition of leadership is evolving. Leaders in the modern era can pull from these previous leadership theories to become more balanced: people who combine decisiveness with the ability to cultivate relationships, motivate, inspire, collaborate, listen, and communicate directly over virtual platforms, across all levels, all the while nurturing others and excelling at their own jobs.

\section{CONCLUSION}

The analysis shows the leadership style proposed to deal with the current situation engendered by the pandemic is not really 
a "new" leadership paradigm, but a more appropriate approach and contextual response to an external situation. Leadership development is a process of growth that uses defining moments like the pandemic as an opportunity for reinvention. Prior to the pandemics, leadership was already moving in this direction as a result of the advent of the 4th industrial revolution with employees/workers asking for more autonomy, flexibility to work from anywhere-anytime, work-life integration, and the unbossing [64] of their organizations. The pandemic accelerated the acceptance of a leadership style away from command and control. Leadership is foremost about transformation. In order to credibly transform others (individuals, teams, and organizations), leaders must first credibly transform themselves. This requires that "new" leaders possess not only the right mindset to lead but also the hard (transactional leadership) and the soft (transformational leadership) capabilities to thrive in this new uncertain world. Leadership is ultimately about kindness, giving people a voice, creating a safe space where they can be their authentic self, and extending them a guiding hand along the way.

\section{ACKNOWLEDGEMENTS}

Eva Golubeva and Jullian Schrup Willamette University 2020 research associates contributed to the research of the impact of COVID-19 on leadership and leadership development.

\section{REFERENCES}

[1] Gans, H. (2016). The Disruption Dilemma. Cambridge: The MIT Press.

[2] Claus, L. \& Monaghan, D. (2019). White Paper: Dynamic Open Talent. A Template for Developing, Implementing, Supporting, and Measuring a Dynamic Open Talent (DOT) Strategy for a Global Company. Redmond, WA: Global HR Consortium/IT Roundtable.

[3] Carlyle, T. (1870). On Heroes, Hero-Worship and the Heroic in History. London: Chapman and Hall.

[4] Galton, F. (1865). Hereditary Talent and Character. Macmillan's Magazine 12: 157-66 \& 318-27.

[5] Ghiselli, E. (1959). Traits Differentiating Management Personnel. Personnel Psychology, 12: 535-544; Ghiselli, E. (1963). Managerial talent. American Psychologist, 18: 631-642.

[6] Stogdill, R. M. (1948). New Patterns Associated with Leadership: A Survey of the Literature. Journal of Psychology, 25: 35-71.

[7] Likert, R. (1961). New Patterns of Management. New York: McGraw-Hill.

[8] Evans, M.G. (1970). The Effects of Supervisory Behavior on Path-Goal Relationships.” Organizational Behavior and Human Performance, 5: 277-298.

[9] House, R.J. (1971). A Path-goal Theory of Leader Effectiveness. Administrative Science Quarterly, 16: 321-328.

[10] Fiedler, F. E. (1974). The Contingency Model: New Directions for Leadership Utilization. Journal of Contemporary Business. 3(4): 65-80.

[11] Fiedler, F.E. \& Garcia, J.E. (1987). New Approaches to Leadership: Cognitive Resources and Organizational Performance. New York: Wiley.
[12] Hersey, P. and Blanchard, K.H. (1969). Life cycle theory of leadership. Training \& Development Journal; Hersey, P. and Blanchard, K.H. (1977). Management of Organizational Behavior: Utilizing Human Resources. New Jersey/Prentice Hall.

[13] Hersey, P. and Blanchard, K.H. (1977). Management of Organizational Behavior: Utilizing Human Resources. New Jersey/Prentice Hall.

[14] Blake, R. R. \& Mouton, J.S. (1964). The Managerial Grid: Key Orientations for Achieving Production through People. Houston: Gulf Publishing.

[15] Lewin, K., Lippitt, R. \& White, R. K. (1939). Patterns of Aggressive Behavior in Experimentally Created Social Climates. Journal of Social Psychology, 10: 271-299.

[16] Bennis, W. \& Nanus, B. (1985). Leaders: The Strategies for Taking Charge. New York: Harper \& Row.

[17] Bennis, W. (2002). Leading Managers to Adapt and Grow. Pp. 212-213 in: Business The Ultimate Resource. Cambridge: Persues Publishing.

[18] Collins, J. (2001). Good to Great: Why Some Companies Make the Leap... and Others Don't. New York: HarperCollins publishers Inc.

[19] Maxwell J.C. (2011). The Five Levels of Leadership: Proven Steps to Maximize Your Potential. New York: Center Street.

[20] Dansereau, F., Graen, G.B. \& Haga, W.J. (1975). A Vertical Dyad Linkage Approach to Leadership within Formal Organizations: A Longitudinal Investigation of the Role Making Process. Organizational Behavior and Human Performance 13: 46-78.

[21] Graen, G. B. \& Uhl-Bien, M. (1995). The Relationship-based Approach to Leadership: Development of LMX theory of Leadership over 25 Years: Applying a Multi-level, Multidomain Perspective. Leadership Quarterly, 6 (2): 219-247.

[22] Adair, J. (1984). Action-Centered Leadership. New York: McGraw-Hill.

[23] Burns, J, M. (1978). Leadership. New York: Harper \& Row.

[24] Bass, B. M. (1985). Leadership: Good, Better, Best. Organizational Dynamics, 13(3): 26-40.

[25] Bass, B. M. (1990). From transactional to transformational leadership: Learning to share the vision. Organizational Dynamics, 18(3): 19-31.

[26] Avolio, B. J. (1999). Full Leadership Development. Building the Vital Forces in Organizations. Thousand Oaks: Sage Publications.

[27] Avolio, B.J. (2005). Leadership Development in Balance: MADE/Born. Mahwah: Lawrence Erlbaum Associates, Inc.

[28] Avolio, B.J. \& Luthans, F. (2005). The High Impact Leader. New York: McGraw-Hill.

[29] Avolio, B. J., \& Gardner, W. L. (2005). Authentic Leadership Development: Getting to the Root of Positive Forms of Leadership. Leadership Quarterly, 16, 315-338.

[30] Covey, S. R. (1989a). The 7 Habits of Highly Effective People. New York: Free Press.

[31] Covey, S.R (1989b). Principle-Centered Leadership, New York: Summit Books.

[32] Chopra, D. (2010). The Soul of Leadership: Unlocking Your Potential for Greatness. New York: Harper Books. 
[33] Goleman, D., Boyatzis, R. \& McKee, A. (2002). Primal Leadership: Realizing the Power of Emotional Intelligence. Boston: Harvard Business School Press. Goleman, D., Boyatzis, R. \& McKee, A. (2002). Primal Leadership: Realizing the Power of Emotional Intelligence. Boston: Harvard Business School Press.

[34] Boyatzis, R. \& McKee, A. (2005). Resonant Leadership. Boston: Harvard Business School Press.

[35] Kouzes, J. and Posner, B. (2002). The Leadership Challenge: How to Make Extraordinary Thing Happen in Organizations. Hoboken: John Wiley and Sons.

[36] Kets de Vries, M. F. R. (2001). The Leadership Mystique: a user's manual for the human enterprise. London: FT Press.

[37] Lipman-Blumen, J. (1996). Connective Leadership: Managing in a Changing World. Oxford: Oxford University Press.

[38] Black, S. B., Morisson, A. J. \& Gregersen, H.H. (1999). Global Explorers: The Next Generation of Leaders. New York: Routledge.

[39] Trompenaars, F. \& Hampden-Turner, C. (2002). 21 Leaders for the 21 st Century: How Innovative Leaders Manage in the Digital Age. New York: Mac Graw Hill.

[40] House, R.J. Hanges, P.J., Javidan, M., Dorfman, P.W. \& Gupta, V. (2004). Culture, Leadership and Organizations: The GLOBE Study of 62 Societies. Thousand Oaks: Sage Publishing.

[41] Mendenhall, M. \& Osland, J.S. (2002). Mapping the Terrain of the Global Leadership Construct. Paper presented at the Academy of International Business, San Juan, Puerto Rico.

[42] Greenleaf, R. K. (1976). The Servant as Leader. Mahwah: Paulist Press.

[43] Dank, N. \& Hellström, R. (2020) Agile HR. Deliver Value in a Changing World of Work. London: Kogan Page Limited.

[44] Helgesen, S. (1990). The Female Advantage: Women's Ways of Leadership. New York: Currency Doubleday.

[45] Chamorro-Premuzic, T. (2019). Why Do So Many Incompetent Men Become Leaders? (And How to Fix It) Harvard Business Review Press, 2019.

[46] Pearce, C. L., \& Conger, J. A., Eds. (2003). Shared Leadership: Reframing the Hows and Whys of Leadership. Thousand Oaks: Sage. Pearce, C. L. (2004). The Future of Leadership: Combining Vertical and Shared Leadership to Transform Knowledge Work. The Academy of Management Executive, 18(1): 47-59.

[47] DuBrin, A.J. (Ed.) (2013). Handbook of Research on Crisis Leadership in Organizations. Cheltenham Glos: Edward Elgas Publishing, Inc.
[48] Weber, R.P. (1990). Basic Content Analysis (2nd. Ed.), Newbury Park: Sage University paper.

[49] Claus, L. Baker, S, \& Vermeulen, P. (2021). From Awesome Manager to Awesome Leader: Fundamentals of Leadership and Leadership Development. In Claus, L., Baker, S. and Vermeulen, P. Be(Come) and Awesome Manager: the Essential Toolkit for Impact Leadership (2nd edition, forthcoming). Silverton: Global Immersion Press.

[50] Rengit, P. (2010). The Heart of Resilient Leadership: Responding to COVID-19: A Guide for Senior Executives. Deloitte.

[51] McKinsey \& Company (2020). Meet Your New Leaders: Supportive, Creative, and Employee-focused.

[52] McKinsey \& Company (2020). A Tale of 2020 in 20 McKinsey Charts.

[53] Kets de Vries, M.F.R (2020). We Get the Leaders We Deserve?

[54] MacDonald, A. (2020). Nine Leadership Lessons 2020 Gave Us. Sloan Management Review.

[55] Koehn, N. (2020). Real Leaders Are Forged in Crisis.

[56] D'Auria, G. \& De Smet, A. (2020). Leadership in a Crisis: Responding to the Coronavirus Outbreak and Future Challenges, McKinsey \& Company.

[57] Homegardner, T. (2020). The Top Three Leadership Skills Needed Post-Pandemic. Forbes.

[58] Pitstick, H. (2020). 4 key leadership skills for a post-COVID-19 workplace. Financial Management Online.

[59] Daimler, M. (2020). Three Leadership Skill Shifts for 2021 and Beyond.

[60] Brownlee, D. (2020). 7 Leadership Traits For The Post COVID19 Workplace. Forbes.

[61] Fernandez, A.S. \& Shaw, G.P. (2020). Academic Leadership in a Time of Crisis: The Coronavirus and COVID-19. Journal of Leadership Studies, 14(1): 39-45.

[62] Agrawal, S., De Smet, A., Lacroix, S. \& Reich, A. (2020). To Emerge Stronger from the COVID-19 Crisis, Companies Should Start Reskilling their Workforces Now. McKinsey \& Company.

[63] Bolden, R (2011). Distributed Leadership in Organizations: A Review of Theory and Research. International Journal of Management Reviews. 13(3): 251-269.

[64] Kolind, L. \& Bǿtter, J. (2012). Unboss. Copenhagen: JyllandPostens Forlag.

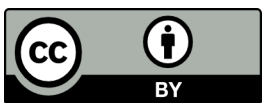

(C) 2021 by the Lisbeth Claus. Submitted for possible open access publication under the terms and conditions of the Creative Commons Attribution (CC $\quad$ BY $)$ license (http://creativecommons.org/licenses/by/4.0/). 